\title{
KAJIAN IMPLEMENTASI KEBIJAKAN ORGANISASI KESATUAN PENGELOLAAN HUTAN (KPH) DI DAERAH (STUDI KASUS KPH BANJAR, KALIMANTAN SELATAN DAN KPH LALAN MANGSANG MENDIS, SUMATERA SELATAN) \\ (Study of Policy Implementation of Forest Management Unit (FMU) \\ Organization in Regency Level) (Case study at Banjar FMU, South Kalimantan and Lalan Mangsang Mendis FMU, South Sumatera)
}

\author{
Oleh / By: \\ Elvida Yosefi Suryandari dan Sylviani ${ }^{2}$ \\ ${ }^{1,2}$ Pusat Penelitian dan Pengembangan Perubahan Iklim dan Kebijakan \\ Jl. Gunung Batu No. 5, Bogor 16118. Telp (0251) 8633944, Fax : (0251) 8634924 \\ Email : elvidays@yahoo.com, sylvireg@yahoo.co.id
}

Diterima 12 Maret 2012, disetujui 1 Juni 2012

\begin{abstract}
Forest Management Units (FMUs) establishment has been laid as a strategic objective to better management of forests. However, problems are still encountered in the development of FMUs, such as institutional framework of its funding and human resources avaibility. This study aims to:(1) analyze the policy implementation of FMU organization; and (2) analyze the availability of buman resources in FMU development. The study was conducted in Lalan Mangsang Mendis FMU, South Sumatra Province and Banjar FMU, South Kalimantan Province. The data were collected using purposive sampling and analyzed using buman resource planning analysis and policy analysis.

The results showed that the current form of FMU organization is a technical implementation unit of "Regional Working Unit" (RWU) of Forestry Office. There is an incompatibility of the structure with the organizational structure of the existing regulation. The organization model has some weaknesses, such as limitations of budget and authority, and lack of human resources (quantity and quality). Regional Working Unit (RWU) form could consist of a secretariat, a service unit, technical unit (TU), or other working unit as part of the regency organizations. Regional Working Unit (RWU) form that is compatible for FMU should be TU or other working unit. According to article 45 on PP41/2007, FMU organizations should not be in form of "TU" but may be an "other working unit", because the existing organization components already reached a maximum score. The current priority should be how to strengthen the FMU institution as "Regional Working Unit" $(R W U)$ with a good planning. Important steps are still needed before the operation of FMU, such as how to determine the role and function of FMU and working relationships with relevant stakeholders including forest license holders, which then should be arranged in the form of regulations. Further, the commitment of local government is needed to support the formation of a FMU as RWU.
\end{abstract}

Key words: Forest Management Unit, form of organization, compatibility and Human Resources 


\begin{abstract}
ABSTRAK
Pembangunan Kesatuan Pengelolaan Hutan (KPH) telah ditetapkan sebagai tujuan strategis untuk mengelola hutan yang lebih baik. Walaupun demikian masih banyak kendala dijumpai dalam pembangunan $\mathrm{KPH}$, diantaranya masalah kelembagaan dalam pendanaan dan pengembangan sumberdaya manusia (SDM). Penelitian ini bertujuan untuk: (1) Mengkaji implementasi kebijakan terkait organisasi KPH dan (2) Mengkaji ketersediaan SDM pendukung dalam pembangunan KPH. Penelitian dilakukan di Kesatuan Pengelolaan Hutan Produksi (KPHP) Lalan Mangsang Mendis, Provinsi Sumatera Selatan dan KPHP Banjar, Provinsi Kalimantan Selatan. Pengumpulan data dilakukan dengan purposive sampling. Data dianalisis dengan analisis perencanaan SDM dan analisis kebijakan.

Hasil penelitian menunjukkan bahwa bentuk organisasi KPH saat ini adalah UPTD dari Satuan Kerja Perangkat Daerah (SKPD) Dinas Kehutanan. Penelitian menunjukkan adanya ketidaksesuaian organisasi UPTD dengan peraturan yang ada. Bentuk organisasi tersebut mempunyai keterbatasan dalam anggaran dan kewenangan pelaksanaan kegiatan, Sumberdaya Manusia (SDM) baik kuantitas dan kualitas. Bentuk SKPD dapat berupa sekretariat, Dinas, Lembaga Teknis Daerah (LTD), atau lembaga lain sebagai bagian dari perangkat daerah. Bentuk KPH yang tepat adalah LTD atau lembaga lain. Sesuai pasal 45 pada PP41/2007 maka organisasi KPH tidak bisa berbentuk "Lembaga Teknis Daerah", tapi dalam bentuk "Lembaga Lain" karena skor organisasi di kabupaten sudah menunjukkan nilai yang maksimal. Kebutuhan saat ini adalah bagaimana memperkuat kelembagaan KPH sebagai SKPD dengan perencanaan yang baik. Langkah-langkah penting masih diperlukan sebelum KPH operasional adalah penentuan peran dan fungsi KPH secara jelas dan tata hubungan kerja dengan stakeholder terkait termasuk pemegang ijin yang dapat dituangkan melalui peraturan. Lebih lanjut, komitmen daerah diperlukan untuk mendukung pembentukan KPH menjadi SKPD.
\end{abstract}

\section{PENDAHULUAN}

Komitmen negara untuk mewujudkan pengelolaan hutan lestari diwujudkan dengan pembentukan unit-unit manajemen kecil dalam kawasan hutan berupa Kesatuan Pengelolaan Hutan (KPH) (UU 41/1999, PP 44/2004, PP 6/2007 jo 3/2008). KPH adalah organisasi yang mewakili entitas kawasan di tingkat lapangan untuk menjamin peningkatan kepastian kawasan dan terselenggaranya keberlanjutan kelola kawasan untuk produksi hasil hutan (kayu dan non kayu), penyerapan karbon dan kesejahteraan masyarakat (Departemen Kehutanan, 2007). Berdasarkan Permenhut P 6/Menhut-II/2009 mengenai Prosedur Pembentukan Wilayah Kesatuan Pengelolaan Hutan (KPH), tahapan pembentukan $\mathrm{KPH}$ terdiri dari : (1) Rancang
Bangun, (2) Arahan Pencadangan, (3) Usulan Penetapan dan (4) Penetapan oleh Mentri Kehutanan. Pembentukan wilayah KPH telah dilakukan pada 23 provinsi yang tersebar di Indonesia, yaitu meliputi 342 unit KPHP dan 179 unit KPHL (Ditjen Planologi, 2011). Keseluruhan berjumlah $521 \mathrm{KPH}$ (tidak termasuk KPHK), dengan 30 unit KPH model termasuk KPH Banjar dan KPH Lalan yang menjadi lokasi penelitian. Prasyarat yang harus dipenuhi dalam pembentukan KPH adalah (1) Penetapan Wilayah KPH, (2)Kelembagaan $\mathrm{KPH}$ yang meliputi aspek organisasi, SDM, Sarpras, pendanaan dan (3) Tersedianya hasil Tata Hutan dan Rencana Pengelolan Hutan.

Upaya untuk mewujudkan pembangunan KPH menemui beberapa permasalahan antara lain :1) Belum dipahaminya dan belum sinerginya Peraturan Perundangan- 
undangan yang yang terkait dalam pembentukan KPH, 2) Perbedaan kesiapan di masing-masing daerah, 3) Belum disepakatinya bentuk organisasi KPH dan (4) Sumber daya manusia (Kartodihardjo, 2008). Hasil penelitian (Suryandari dan Sylviani, 2009) menunjukkan bahwa pembangunan $\mathrm{KPH}$ sangat dipengaruhi oleh aspek kelembagaan yaitu bentuk dan struktur organisasi dan peraturan pendukung. Aspek lain yang berpengaruh adalah dalam perencanaan, utamanya tingkat kematangan master plan yang dibuat, masalah pendanaan dan tata batas kawasan.

Pembangunan KPH tidak terlepas dari masalah bentuk struktur organisasi yang selanjutnya akan mempengaruhi pelaksanaan KPH. Suryono (2010) menjelaskan bahwa organisasi adalah suatu sistem yang terdiri dari pola aktivitas kerjasama yang dilakukan secara teratur dan berulang-ulang oleh sekelompok orang untuk mencapai suatu tujuan tertentu. Lebih lanjut, Suryono (2010) menjelaskan bahwa perilaku suatu organisasi dipengaruhi oleh 4 unsur antara lain struktur, orang atau SDM, teknologi dan lingkungan (kebijakan dan aturan). Kebijakan organisasi $\mathrm{KPH}$ yaitu Peraturan Menteri Dalam Negeri No 61 tahun 2010 tentang Pedoman Organisasi dan Tata Kerja KPHP dan KPHL menjadi tantangan tersendiri bagi daerah karena adanya perbedaan kesiapan setiap daerah untuk membangun KPH. Secara umum penelitian ini bertujuan untuk (1) Mengidentifikasi organisasi KPH di daerah, (2) Mengkaji implementasi kebijakan terkait organisasi $\mathrm{KPH}$ dan (3) Mengkaji ketersediaan SDM pendukung dalam pembangunan $\mathrm{KPH}$.

\section{METODE PENELITIAN}

\section{A. Lokasi Penelitian}

Penelitian difokuskan pada Kesatuan Pengelolaan Hutan Model yaitu KPHP Banjar (Provinsi Kalimantan Selatan) dan KPHP Lalan Mangsang Mendis (Provinsi Sumatera Selatan).

\section{B. Kerangka Analisis}

Berdasarkan penjelasan Pasal 8 ayat $1 \mathrm{PP}$ No 3 tahun 2008, organisasi KPH diharapkan menjadi organisasi yang mampu menyelenggarakan pengelolaan yang dapat menghasilkan nilai ekonomi, mengembangkan investasi dan menggerakkan lapangan kerja, memiliki kompetensi perencanaan dan melindungi kepentingan publik, mampu menjawab dampak pengelolaan secara global seperti perubahan iklim dan berbasis profesionalisme kehutanan. Untuk menjadi organisasi seperti yang disebutkan di atas diperlukan strategi pengelolaan hutan lestari termasuk masalah pendanaan dan ketersediaan SDM dalam kegiatan pengelolaan $\mathrm{KPH}$.

Kerangka analisis penelitian ini dilakukan dengan melihat Peraturan Pemerintah No. 6 tahun 2007 jo No 3 tahun 2008 tentang Tata Hutan Dan Penyusunan Rencana Pengelolaan Hutan, Serta Pemanfaatan Hutan, bahwa persyaratan suatu organisasi KPH telah mengakomodir pengelolaan hutan lestari secara utuh. Selanjutnya dilakukan analisis terhadap organisasi $\mathrm{KPH}$ yang ada dengan analisis SDM dan analisis kebijakan untuk dapat memberikan rekomendasi kebijakan. Rincian kerangka analisis penelitian dapat dilihat pada Gambar 1. 


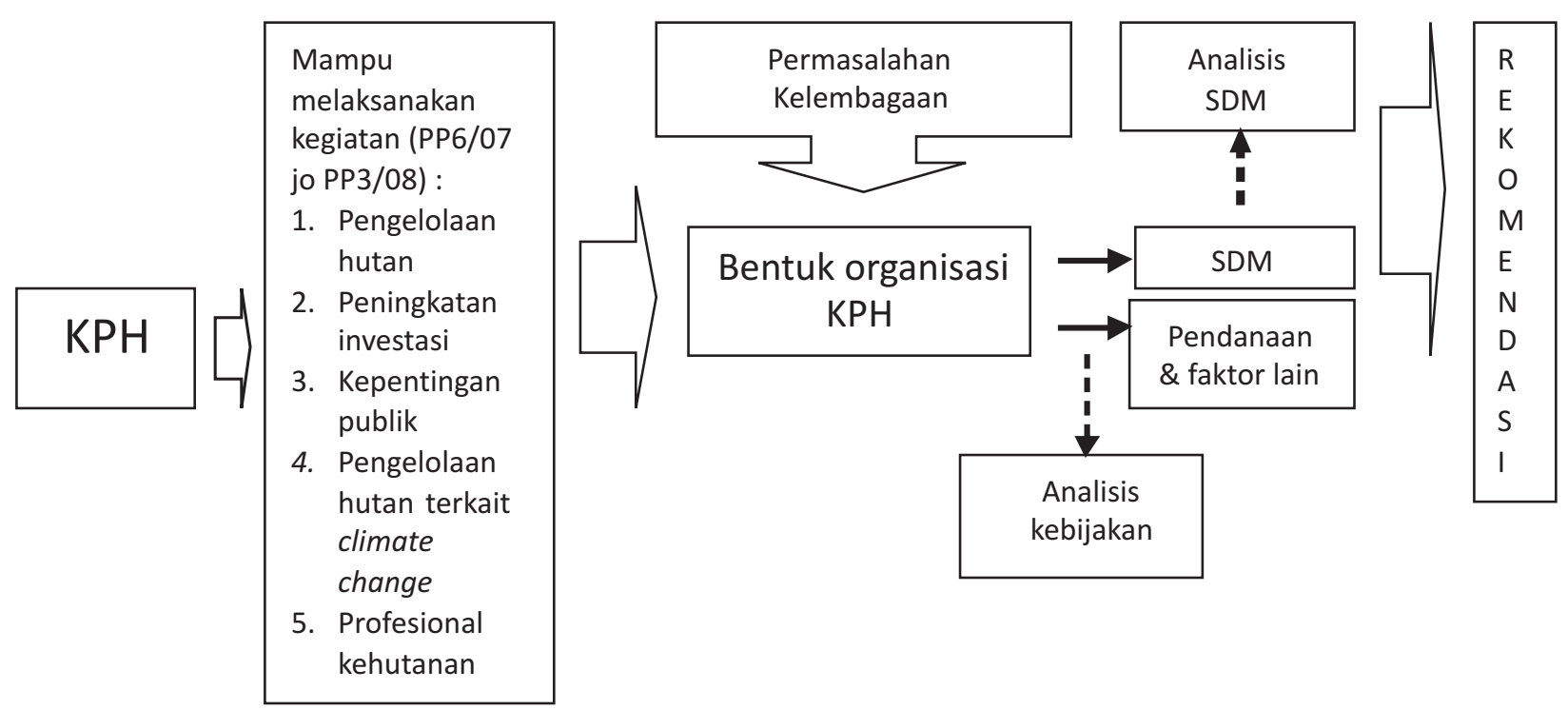

Gambar 1. Kerangka analisis penelitian

Figure 1. Framework of research analysis

\section{Pengumpulan Data}

Pengumpulan data dilakukan dengan teknik sampling secara purposive. Teknik sampling ini dilakukan melalui penentuan sampel dengan mempertimbangkan kriteriakriteria tertentu yang telah dibuat terhadap obyek yang sesuai dengan tujuan penelitian yaitu para pihak yang terkait dalam pembangunan KPH. Pengumpulan data dilakukan dengan beberapa cara antara lain:

1. Studi literature dan pencatatan, yaitu mempelajari dokumen dan literatur yang berkaitan dengan pengelolaan KPH di Pusat, Provinsi, Kabupaten.

2. Wawancara mendalam, yaitu melakukan wawancara kepada instansi pemerintah terkait (Pusat, Provinsi, Kabupaten).

3. Pengamatan lapangan untuk melihat kondisi pengelolaan KPH.

\section{Analisis Data}

1. Kajian ini difokuskan untuk mengkaji implementasi suatu kebijakan yaitu Permendagri 61/2010, dengan cara mengetahui pengaruh apa saja yang terjadi setelah suatu peraturan ditetapkan. Menurut Patton dan Sawicki dalam (Azhar, 2008) tahap implementasi berkaitan dengan berbagai kegiatan yang diarahkan untuk merealisasikan program, dimana pemerintah mengatur cara-cara untuk menerapkan kebijakan (dalam bentuk regulasi) sehingga mampu mengatur secara efektif dan efisien sumberdaya, unit teknis dan prosedur yang mendukung pelaksanaan program. Kesesuaian suatu kebijakan atau peraturan perundang-undangan tidak bisa dilihat hanya dari materi muatan dan hierarkinya (normatif). Selain aspek normatif, suatu analisis kebijakan menyeluruh menyangkut implementasi kebijakan (positif) harus dikaji secara bersama-sama (Nurrochmat, 2010).

2. Untuk mengetahui kemungkinan alokasi dan ketersediaan sumber daya manusia (SDM) dalam organisasi $\mathrm{KPH}$ dilakukan pendekatan deskriptif kualitatif melalui pendekatan analisis Perencanaan 
Sumberdaya Manusia (PSDM) yang merupakan proses analisis dan identifikasi tersedianya kebutuhan akan sumber daya manusia sehingga organisasi yang baru dapat operasional. Pengembangan rencana SDM merupakan rencana jangka panjang dalam suatu organisasi dalam mempertimbangkan alokasi orang-orang pada tugasnya sesuai tujuan organisasi (Parwiyanto,2009). Prosedur perencanaan SDM antara lain (a) Menetapkan secara jelas kualitas dan kuantitas SDM yang dibutuhkan sesuai tujuan organisasi, (2) Mengumpulkan data dan informasi tentang SDM, (3) Mengelompokkan data dan informasi serta menganalisisnya dan (4) Menetapkan alternatif termasuk kemungkinan mobilisasi SDM.

\section{HASIL DAN PEMBAHASAN}

\section{A. Perkembangan KPH di Lokasi Penelitian}

Penetapan wilayah KPH sesuai Kemenhut No. SK.78/MENHUT-II/2010 tanggal 10 Februari 2010 untuk provinsi Kalimantan Selatan terdiri dari : 3 (tiga) unit KPHL (331.418 ha) dan 7 (tujuh) unit KPHP (1.072.343 ha). Dari ketujuh KPH tersebut terdapat 1 unit $\mathrm{KPH}$ model yaitu : KPHP Model Banjar seluas 139.957 hektar di Kabupaten Banjarbaru yang ditetapkan berdasarkan Surat Keputusan Menteri Kehutanan No.793/Menhut-II/2009 tanggal 7 Desember 2009. Penetapan wilayah KPHP Model Banjar berdasarkan fungsi hutan dapat dilihat pada Tabel 1 berikut :
Tabel1. Kawasan hutan berdasarkan fungsinya di KPH Banjar

Table 1. Forest area based on its function in Banjar FMU

\begin{tabular}{ccc}
\hline No & $\begin{array}{c}\text { Fungsi hutan } \\
\text { (Forest function) }\end{array}$ & $\begin{array}{c}\text { Luas (area) } \\
\text { (ha) }\end{array}$ \\
\hline 1 & Hutan Produksi Terbatas & 25.354 \\
2 & Hutan Produksi Tetap & 72.513 \\
3 & Hutan Lindung & 42.090 \\
\hline & Total & 139.957 \\
\hline
\end{tabular}

Sumber (Source): Dinas Kehutanan Banjar (2010) (Banjar Forestry Office, 2010)

Kawasan KPHP Banjar memiliki luasan hutan produksi yang cukup besar yaitu hutan produksi terbatas seluas 25.354 ha $(18,1 \%)$, hutan produksi tetap seluas 72.513 ha $(51,8 \%)$ dan sedikit hutan lindung seluas $42.090(30,1 \%)$ (Tabel 1). Berdasarkan wilayah administrasi maka wilayah KPH Banjar meliputi 5 (lima) kecamatan yang didalamnya terdapat penduduk yang bermukim yaitu Kecamatan Pengaron (4.572 KK), Peramasan (1.014 KK), Sungai Pinang (4.350 KK), Sambung Makmur (2.455 KK) dan Telaga Bauntung (1.015 KK) (Dinas Kehutanan Banjar, 2010). Pemanfaatan lahan di KPHP Banjar antara lain untuk pemukiman, transmigrasi, KHDTK dan pemegang ijin. Untuk lebih jelas dapat dilihat kawasan KPH Banjar pada Gambar 2. 


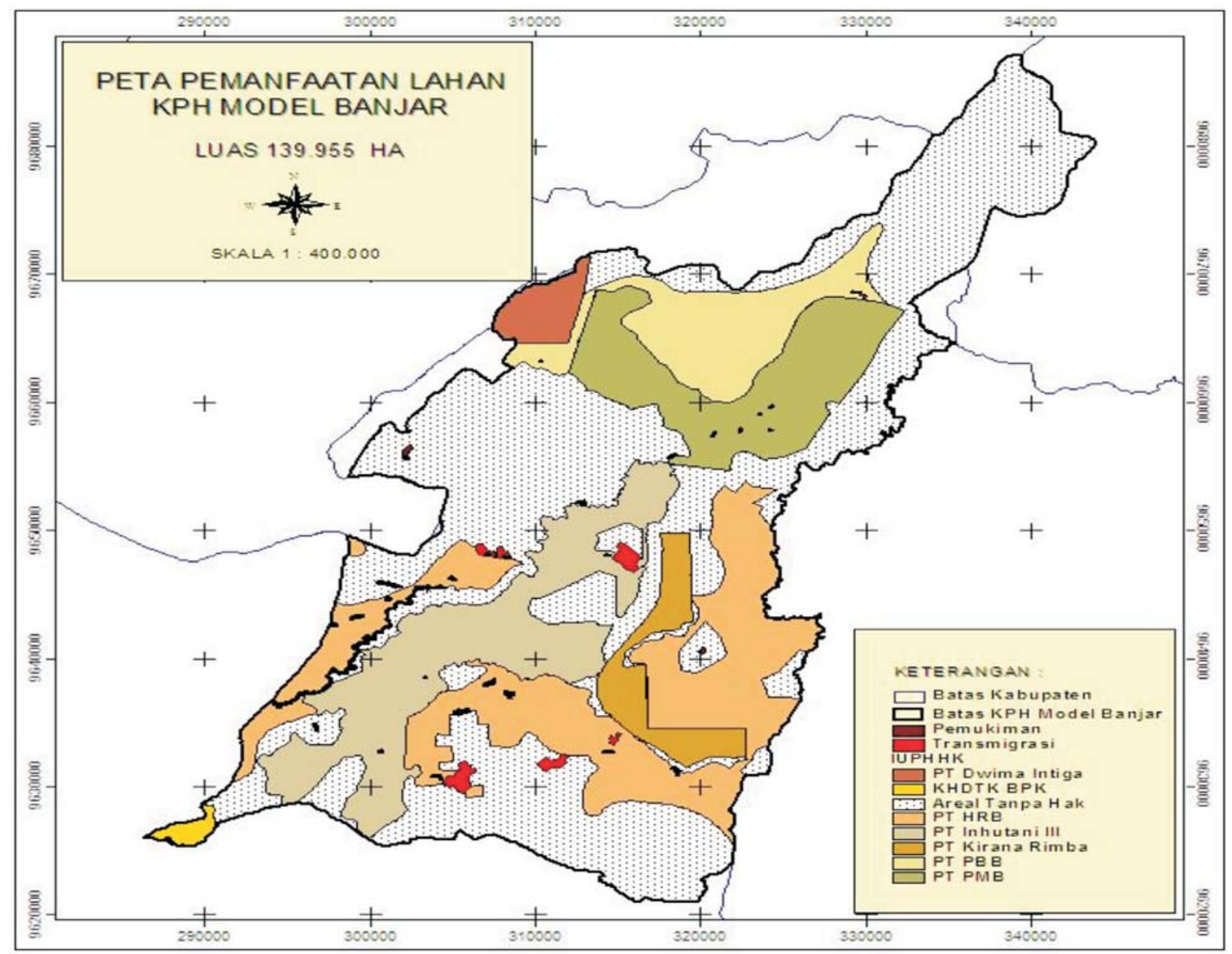

Gambar 2. Peta Pemanfaatan Lahan KPH Banjar (KPH Banjar, 2010)

Figure 2. Landuse map of Banjar FMU(Banjar FMU, 2010)

Sementara itu pemerintah Provinsi Sumatera Selatan telah mengusulkan Penetapan wilayah KPH Produksi dan KPH Lindung sesuai surat Gubernur Sumatera Selatan Nomor 522/0064/Hut/2010 tanggal 11 Januari 2010 dan telah ditetapkan oleh Menteri Kehutanan sesuai Keputusan Menteri No. SK.76/Menhut-II/2010 tanggal 10 Pebruari 2010. Penetapan Kawasan Hutan di Provinsi Sumatera Selatan terbagi menjadi 24 Unit KPH terdiri dari 14 unit KPH Produksi seluas 2.059.461 ha dan 10 unit KPH Lindung seluas 498.941 ha. KPH model di Sumsel yang ditetapkan berdasarkan Keputusan Menteri Kehutanan Nomor SK. 789/MENHUT-
II/2009 tanggal 7 Desember 2009 adalah KPH Produksi Model Lalan Mangsang Mendis (LMM) di Kabupaten Musi Banyuasin seluas 265.953 ha (12,9\% dari luas hutan produksi). KPHP ini terdiri dari 2 (dua) kelompok hutan yaitu HP Lalan dan HP Mangsang Mendis, wilayah kawasannya masuk DAS Banyuasin Sub DAS Lalan yang bermuara ke Sungai Banyuasin dan Selat Bangka.

Pemanfaatan lahan dalam kawasan KPHP Lalan Mangsang Mendis antara lain pemegang ijin Hutan Tanaman Industri (HTI), HTR dan hutan desa, lebih lanjut dapat dilihat pada Gambar 3. 


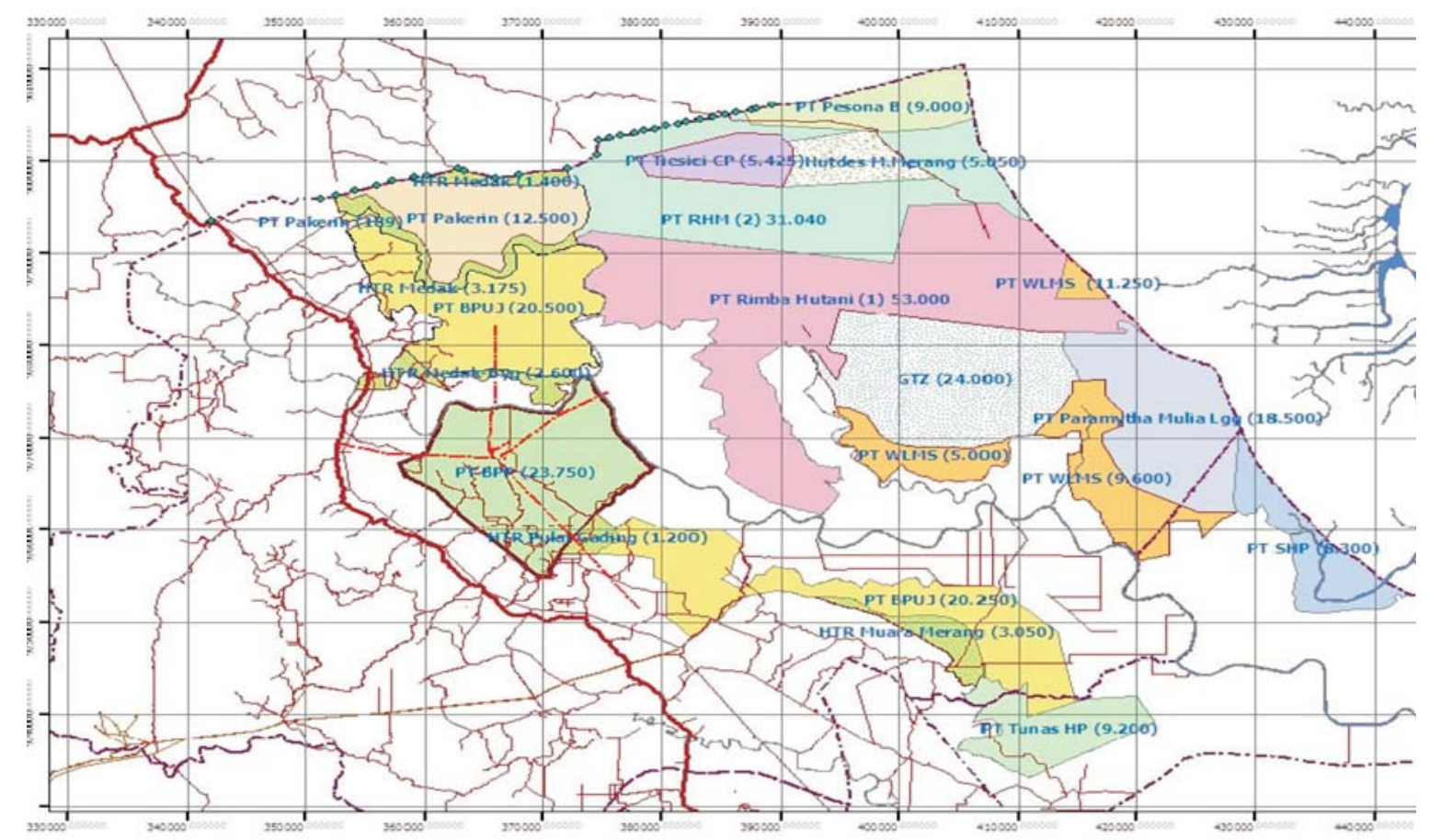

Gambar 3. Peta pemanfaatan lahan di KPH Lalan Mangsang Mendis Figure 3. Land use map of Lalan Mangsang Mendis FMU

\section{B. Identifikasi Organisasi KPH}

Fakta yang terjadi adalah terdapat permasalahan kelembagaan dalam pembangunan $\mathrm{KPH}$ yaitu bentuk organisasinya termasuk terkait masalah SDM dan pengaturan pendanaan. Bentuk organisasi $\mathrm{KPH}$ model didasarkan pada masing-masing Peraturan Daerah baik di provinsi maupun kabupaten yang berbentuk Unit Pelaksana Teknis Daerah (UPTD) Dinas Kehutanan.

\section{KPH Banjar}

KPHP Banjar telah membentuk institusi pengelola berupa UPT di bawah Dinas Kehutanan Kabupaten Banjar. Struktur organisasi UPT KPHP Banjar disajikan pada Gambar 4, dimana struktur organisasi terdiri dari kepala UPT KPH Banjar, Tata usaha dan tenaga fungsional. Berdasarkan PP no 6 tahun 2007 jo PP no 3 tahun 2008 pasal 9 dan pasal 12 tentang pengelolaan hutan; Kepala KPH minimal akan membawahi : seksi operasional (Tata Usaha); seksi perencanaan dan pemetaan; seksi pemanfaatan dan perlindungan; seksi rehabilitasi dan reklamasi; dan tim Adhoc. Organisasi KPH bertugas menyelenggarakan pengelolaan hutan sesuai dengan fungsi hutannya dan melaksanakan kebijakan baik pemerintah pusat maupun daerah yang berhubungan dengan kehutanan. Tim ad-hoc dibentuk berdasarkan keperluan; terutama saat awal dalam melaksanakan kegiatan tata hutan dan penyusunan rencana pengelolaan hutan jangka panjang dan jangka pendek. Dalam hal ini terdapat ketidaksesuaian antara struktur organisasi yang telah terbentuk dengan uraian organisasi KPH berdasarkan PP no 6 tahun 2007 jo PP no 3 tahun 2008. 


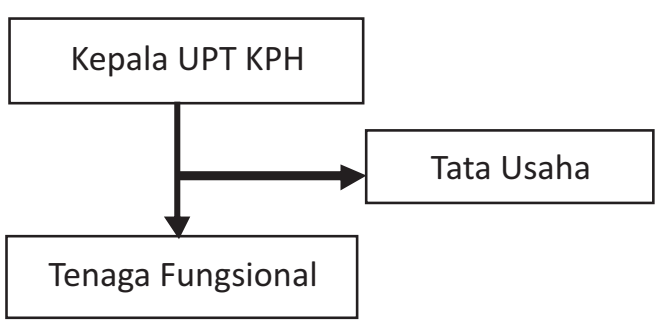

Gambar4. Struktur organisasi KPH Banjar Figure 4. The organizational structure of Banjar FMU

Jumlah SDM yang ada hingga saat penelitian di KPH Model Banjar sebanyak 10 orang, terdiri dari Kepala KPH; Kepala Tata Usaha; dan 5 orang Tenaga Fungsional serta 3 orang tenaga lapangan (SK Bupati Banjar no 13 Tahun 2009 tentang Pembentukan Organisasi UPT KPH, tanggal 1 Juli 2009). Kegiatan yang telah dilakukan KPHP Banjar antara lain : sosialisasi, inventarisasi potensi, dan pembentukan Demonstration Plot (Demplot) dengan melibatkan masyarakat dengan sumber dana pengelolaan KPH berasal dari APBD pada DIPA Dinas Kehutanan Kabupaten Banjar.

\section{KPHP Lalan Mangsang Mendis}

Berdasarkan Peraturan Bupati Banyuasin No. 24 Tahun 2009 tentang Pembentukan Unit Pelaksana Tekni Dinas (UPTD) Kesatuan Pengelolaan Hutan Produksi (KPHP) Lalan Mangsang Mendis Dinas Kehutanan Kabupaten Musi Banyuasin, struktur organisasi UPTD KPH Lalan Mangsang Mendis adalah sebagai berikut (Gambar 5) :

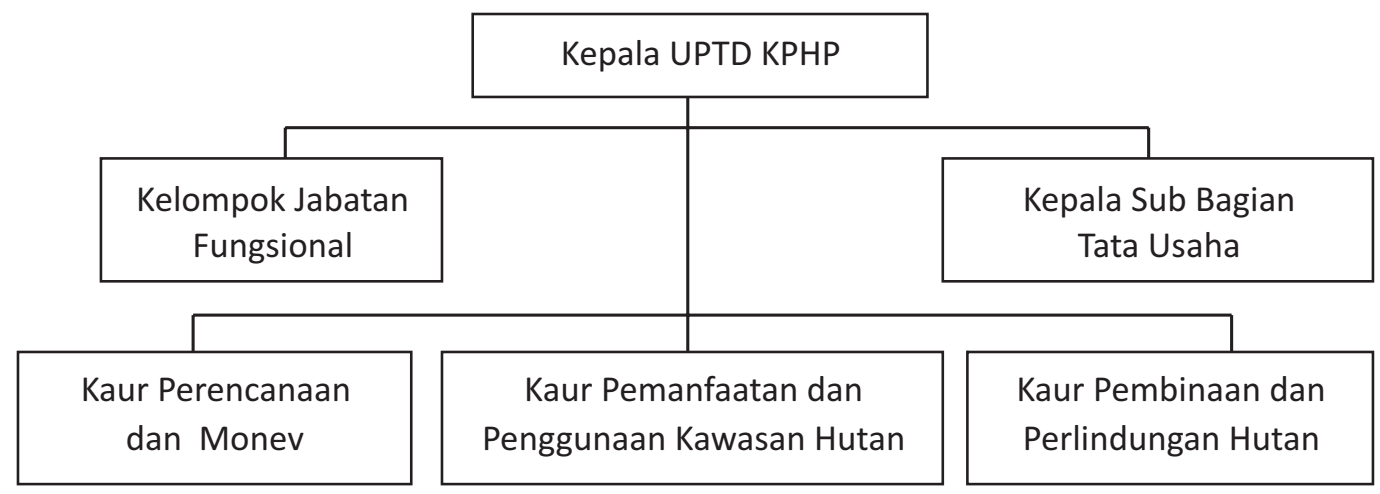

Gambar 5. Struktur organisasi KPH Lalan Mangsang Mendis

Figure 5. The organizational structure of Lalan Mangsang Mendis FMU

Struktur organisasi KPH Lalan terdiri dari Kepala UPTD; Kepala Sub Bag Tata Usaha;Kepala Urusan (Kaur) Perencanaan dan Monev; Kaur pemanfaatan dan penggunaan kawasan; Kaur pembinaan dan perlindungan hutan; dan jabatan Fungsional. Eksistensi SATGAS POLHUT sebagai satuan tugas fungsional di KPHP Lalan Mangsang Mendis adalah sebagai kontribusi penguatan kelembagaan KPHP sebelum KPHP memiliki Forest Ranger.
Beberapa permasalahan yang timbul dengan bentuk UPTD KPH, antara lain :

\section{a. Keterbatasan anggaran}

Tidak memiliki Satker sendiri sehingga terbatas dalam mendapatkan anggaran $( \pm$ 20\% dari anggaran Dinas Kehutanan).

\section{b. Keterbatasan pelaksanaan kegiatan}

Kegiatan harus mengacu kepada program yang telah dibuat oleh Pemerintah Daerah yang berkaitan dengan kehutanan melalui kegiatan Dinas kehutanan. 


\section{c. Keterbatasan SDM}

Sumberdaya manusia umumnya masih berasal dari Dinas Kehutanan terkait dimana kualitas SDM masih terbatas.

\section{d. Ketidaksesuaian struktur organisasi}

Organisasi KPH bertugas menyelenggarakan pengelolaan hutan sesuai dengan fungsi hutannya dan melaksanakan kebijakan baik pemerintah pusat maupun daerah yang berhubungan dengan kehutanan. PP no 6 tahun 2007 jo PP no 3 tahun 2008 pasal 9 dan pasal 12; dimana Kepala KPH minimal membawahi 4 seksi dan Tim Adboc (dibentuk berdasarkan keperluan; terutama saat awal dalam kegiatan tata hutan dan penyusunan rencana pengelolaan hutan jangka panjang dan jangka pendek). Struktur organisasi pada kedua KPH menunjukkan bentuk yang berbeda, dimana KPH Lalan struktur organisasi telah mengacu pada PP No 3 tahun 2008 sementara KPH Banjar belum mengakomodir untuk seksi perencanaan dan pemetaan; seksi pemanfaatan dan perlindungan; seksi rehabilitasi dan reklamasi; hal ini dikuatirkan akan mempengaruhi pelaksanaan teknis pengelolaan hutan kedepan.

\section{Implementasi Kebijakan Organisasi $\mathrm{KPH}$}

Sebelum ditetapkannya Permendagri No 61 tahun 2010, telah terjadi proses rancangan peraturan bersama 3 (tiga) menteri antara lain Menteri Kehutanan, Menteri Pendayagunaan
Aparatur Negara (Menpan) dan Menteri Dalam Negeri (Mendagri) tentang organisasi KPH. Melalui surat No. 061/4206/SJ oleh Mendagri ke Menpan tanggal 30 Nopember 2009, dan ditanggapi oleh Menpan melalui surat No. B/858/M.PAN-RB/4/2010 tanggal 13 April 2010. Kementerian PAN menyarankan bahwa organisasi KPH berbentuk UPTD, di lain pihak bentuk UPTD memiliki beberapa kelemahan sehingga perlu dilakukan pembahasan lebih lanjut.

Permendagri No 61 tahun 2010 tentang Pedoman Organisasi dan Tata Kerja Kesatuan Pengelolaan Hutan Lindung dan Kesatuan Pengelolaan Hutan Produksi di Daerah, menyatakan bahwa organisasi KPHP dan KPHL merupakan Satuan Kerja Perangkat Daerah (SKPD); sesuai dengan PP No 41 tahun 2007 tentang Organisasi Perangkat Daerah Kabupaten, paragraph 2 mengenai "Jumlah Besaran Organisasi "(pasal 21 butir 3) yang ditentukan oleh jumlah penduduk, luas wilayah dan besarnya APBD. Berdasarkan kriteria untuk scoring besaran organisasi (PP 41 tahun 2007) yaitu apabila jumlah penduduk suatu kabupaten berkisar antara 450.001 600.000 , skor mencapai 32; luas wilayah lebih dari $2000 \mathrm{~km}^{2}$ akan memiliki skor 35 . Selanjutnya untuk kriteria APBD yaitu apabila jumlah APBD suatu kabupaten mencapai 800 milyar memiliki skor 20 , sedangkan besar APBD lebih dari 800 milyar memiliki skor 25 . Lebih lanjut perhitungan skor organisasi untuk Kabupaten Musi Banyuasin dan Kabupaten Banjar dapat dilihat pada Tabel 2. 
Tabel 2. Penilaian organisasi berdasarkan skor di Kabupaten Muba dan Banjar.

Table 2. Appraisal of organization based on scoring in Muba and Banjar regencies

\begin{tabular}{lcc}
\hline $\begin{array}{c}\text { Kriteria(Criteria) } \\
\text { PP 41/2007 }\end{array}$ & $\begin{array}{c}\text { Kabupaten Muba(Skor) } \\
\text { (Muba regency/score) }\end{array}$ & $\begin{array}{c}\text { Kabupaten Banjar(Skor) } \\
\text { (Banjar regency/score) }\end{array}$ \\
\hline Penduduk & $561.458(32)$ & 489.056 jiwa $(32)$ \\
Luas wilayah & $14.265,96 \mathrm{~km}^{2}(35)$ & $4.660,50 \mathrm{~km}^{2}(35)$ \\
APBD & $1.217 .963 .229 .543(25)$ & $800.705 .462 .175(20)$ \\
\hline \multicolumn{1}{c}{ Total skor } & 92 & 87 \\
\hline
\end{tabular}

Sumber : Data sekunder diolah (Pemda Banjar dan Pemda Muba tahun 2010)

Source: Secondary data processed (Banjar and Muba local government year 2010)

Berdasarkan hasil penilaian skor untuk Kabupaten Banyuasin adalah 92, sementara Kabupaten Banjar sebesar 87, hal ini menunjukkan bahwa kedua kabupaten memiliki skor lebih dari 70 dimana besaran organisasi perangkat daerah kabupaten dengan nilai lebih dari 70 (tujuh puluh) adalah seperti pada Tabel 3. Apabila total skor organisasi di daerah lebih dari 70 (tujuh puluh) maka jumlah SKPD tidak boleh melebihi ketentuan yang telah ditetapkan dalam PP 41 tahun 2007.

Tabel 3. Jumlah organisasi perangkat daerah di kabupaten Muba dan Banjar Table 3. Number of the organization components in Muba and Banjar regencies

\begin{tabular}{lccc}
\hline $\begin{array}{c}\text { Organisasi Perangkat } \\
\text { Daerah }\end{array}$ & $\begin{array}{c}\text { PP 41/2007 } \\
\text { skor }>70 \\
\text { (RKegional organization) }\end{array}$ & $\begin{array}{c}\text { Kabupaten Muba } \\
\text { (Muba regency) } \\
\text { (SKPD) }\end{array}$ & $\begin{array}{c}\text { Kabupaten Banjar } \\
\text { (Banjarregency) } \\
\text { (SKPD) }\end{array}$ \\
\hline Sekretariat Daerah & 4 & 1 & 4 \\
Sekretariat DPRD & 1 & 1 & 1 \\
Dinas & 18 & 18 & 18 \\
Lembaga Teknis & 12 & 13 & 12 \\
Daerah & & & \\
\hline
\end{tabular}

Sumber : Data sekunder diolah (Pemda Banjar dan Pemda Muba tahun 2010)

Source: Secondary data processed (Banjar and Muba local government year 2010)

Tabel 3 menunjukkan jumlah SKPD saat ini di kedua kabupaten dimana dinas dan Lembaga Teknis Daerah (LTD) sudah mencapai jumlah yang maksimal sehingga tidak memungkinkan KPH berbentuk LTD. Kemungkinan pembentukan SKPD baru adalah dalam bentuk "Lembaga Lain" sesuai pasal 45 pada PP41/2007 yaitu pembentukan lembaga lain untuk melaksanakan tugas dan fungsi sebagai perangkat daerah sesuai peraturan perundangan (Permenhut, Permendagri dan PP41/2007). Bentuk lembaga lain yang sudah terbentuk di kabupaten adalah Komisi Penyiaran Daerah, Badan Penanggulangan Bencana Alam, Sekretariat Korpri, Badan Penyuluhan Pertanian, Peternakan dan Kehutanan, Badan Pengawasan Perbatasan dan lainnya. Dengan demikian kedua KPH model tersebut dapat berbentuk Lembaga Lain yang setara dengan Lembaga Teknis Daerah.

Berdasarkan Zainudin (2010) bahawa perubahan organisasi pemerintahan daerah dapat dipengaruhi oleh faktor eksternal yang terdiri dari politik, sosial budaya dan organisasi 
lain terkait dan faktor internal antara lain tujuan organisasi, struktur organisasi, kepemimpinan dan sumberdaya fisik. Berdasarkan hasil wawancara, faktor eksternal dan internal yang mempengaruhi perubahan organisasi UPTD KPH menjadi SKPD dapat dilihat pada Tabel 4.

Tabel 4. Faktor yang mempengaruhi perubahan organisasi dari UPTD menjadi SKPD Table 4. Factors that influence changes in the organization of UPTD to become SKPD

\begin{tabular}{|c|c|c|c|c|c|c|}
\hline \multicolumn{3}{|c|}{ Eksternal (External) } & \multicolumn{4}{|c|}{ Internal (Internal) } \\
\hline Politik/hukum & Sosbud & $\begin{array}{l}\text { Organisasi } \\
\text { lain terkait }\end{array}$ & $\begin{array}{l}\text { Tujuan } \\
\text { organisasi, } \\
\text { Visi dan misi }\end{array}$ & $\begin{array}{l}\text { Struktur } \\
\text { organisasi }\end{array}$ & $\begin{array}{l}\text { Kepemim } \\
\text { pinan }\end{array}$ & $\begin{array}{l}\text { Sumberdaya fisik } \\
\text { Pendanaan }\end{array}$ \\
\hline $\begin{aligned} & \text { 1. } \text { PP6/2007 jo } \\
& \text { PP3/2008 } \\
& \text { 2. } \text { Permendagri } \\
& 61 / 2010 \\
& \text { 3. } \text { PP 41/2007 } \\
&\end{aligned}$ & $\begin{array}{l}\text { Perubahan } \\
\text { tata nilai } \\
\text { masyarakat }\end{array}$ & $\begin{array}{l}\text { Interaksi } \\
\text { dgn } \\
\text { organisasi } \\
\text { lain }\end{array}$ & $\begin{array}{l}\text { Hutan lestari, } \\
\text { ekonomi } \\
\text { berkelanjutan }\end{array}$ & $\begin{array}{l}\text { Hirarki, } \\
\text { SDM }\end{array}$ & $\begin{array}{l}\text { Kesamaan } \\
\text { persepsi }\end{array}$ & $\begin{array}{l}\text { Kelengkapan } \\
\text { sarpras }\end{array}$ \\
\hline $\begin{array}{l}\text { Bentuk masih } \\
\text { UPTD } \\
\text { Kepentingan } \\
\text { politik dan } \\
\text { ekonomi } \\
\text { daerah } \\
\text { Kehutanan } \\
\text { urusan pilihan, } \\
\text { berdasarkan } \\
\text { pertimbangan } \\
\text { kondisi, } \\
\text { kekhasan dan } \\
\text { potensi } \\
\text { unggulan } \\
\text { daerah. }\end{array}$ & $\begin{array}{l}\text { Masalah } \\
\text { tenurial baik } \\
\text { masyarakat } \\
\text { atau } \\
\text { pemegang } \\
\text { IUPHHK }\end{array}$ & $\begin{array}{l}\text { Sinkronisasi } \\
\text { kegiatan } \\
\text { KPH dengan } \\
\text { UPT pusat, } \\
\text { pemda, } \\
\text { pemegang } \\
\text { ijin, } \\
\text { masyarakat }\end{array}$ & $\begin{array}{l}\text { Belum } \\
\text { operasional } \\
\text { sepenuhnya, } \\
\text { baru persiapan } \\
\text { dlm organisasi } \\
\text { UPTD } \\
\text { Keterbatasan } \\
\text { kewenangan } \\
\text { dalam } \\
\text { pengelolaan } \\
\text { kawasan } \\
\text { (Dinas hanya } \\
\text { sebagai } \\
\text { regulator) }\end{array}$ & $\begin{array}{l}\text { Terbatas- } \\
\text { nya SDM } \\
\text { yang } \\
\text { profesion } \\
\text { al }\end{array}$ & $\begin{array}{l}\text { Masih } \\
\text { ditemukan } \\
\text { perbedaan } \\
\text { persepsi }\end{array}$ & $\begin{array}{l}\text { Ketergantungan } \\
\text { pada pusat masih } \\
\text { cukup tinggi } \\
\text { dalam pengadaan } \\
\text { sarpras, karena } \\
\text { keterbatasan } \\
\text { daerah dalam } \\
\text { pendanaan } \\
\text { Untuk menjadi } \\
\text { KPH mandiri } \\
\text { masih } \\
\text { membutuhkan } \\
\text { waktu yang } \\
\text { lama. } \\
\text { Dengan satker } \\
\text { sendiri maka } \\
\text { KPH lebih } \\
\text { leluasa } \\
\text { mengelola } \\
\text { pendanaan } \\
\text { (dibanding } \\
\text { UPTD) }\end{array}$ \\
\hline
\end{tabular}

Sumber (Source) : Data primer diolah (Primary data processed)

UPTD KPH bisa ditingkatkan menjadi SKPD perlu diikuti oleh adanya komitmen daerah yaitu melalui peraturan gubernur/ bupati sekaligus dukungan pusat untuk memfasilitasi pembangunan KPH. Volume kegiatan dan kewenangan juga harus jelas antara Dishut selaku penyelenggara pengurusan hutan yang melakukan pelayanan administrasi pengurusan seperti perijinan dan $\mathrm{KPH}$ selaku penyelenggara pengelolaan yaitu teknis pengelola kawasan. Untuk melakukan perubahan organisasi menjadi organisasi perangkat daerah, perlu dilakukan evaluasi organisasi dari daerah. Tim evaluasi organisasi terdiri dari bupati sebagai pelindung, sekda sebagai penasihat, sekretaris, staf ahli dan lainlain yang bertugas untuk mengevaluasi semua SKPD. Tim ini akan mengkaji seberapa penting pemerintah daerah untuk membentuk organisasi perangkat daerah yang baru berdasarkan beberapa pertimbangan kriteria. Pembentukan SKPD baru tim evaluasi akan mempertimbangkan kriteria-kriteria antara lain: 
a. Kebutuhan (anggaran dan SDM) daerah

b. Potensi daerah

c. Cirikhas daerah

d. Perlu menerapkan prinsip "miskin struktur dan kaya fungsi” dan mempertimbangkan apakah penambahan SKPD benarbenar diperlukan daerah atau malah menambah beban biaya daerah.

e. Seberapa besar volume dan gambaran kegiatan KPH yang jelas sehingga harus dibentuk SKPD baru

f. Bagaimana tata hubungan kerja SKPD KPH dengan Dinas Kehutanan

Permasalahan dalam transisi UPTD KPH menjadi SKPD baru adalah : pada tahap pembahasan oleh DPRD tentang pembentukan lembaga lain yang sangat tergantung pada kebijakan politis daerah, urusan kehutanan sebagai pilihan. Salah satu tantangan adalah bagaimana meyakinkan DPRD untuk membentuk organisasi $\mathrm{KPH}$ yang disertai komitmen dan kebijakan politis daerah yang mendukung serta naskah akademik yang komprehensif sehingga kerjasama dengan universitas dan instansi terkait sangat diperlukan.

Untuk merubah organisasi KPH, Dinas Kehutanan Kabupaten mengusulkan ke Pemda dengan kelengkapan data terkait. Tugas Biro Hukum Pemda Kabupaten adalah memproses pembuatan perda untuk perubahan organisasi UPTD KPH menjadi SKPD.

a. Tugas Biro Hukum adalah mendampingi Dinas Kehutanan untuk draffting perda, dimana draft perda harus dilengkapi oleh :

Dasar-dasar hukum dan referensi terkait pembentukan SKPD tersebut.

Draft naskah akademik yang menggambarkan latar belakang kepentingan dan manfaat terbentuknya SKPD KPH, dan hal ini akan menentukan kelayakan pembentukan organisasi yang dimaksud.

b. Proses pembahasan Perda untuk pembentukan SKPD KPH

Beberapa tahap yang harus dilakukan dalam pembentukan SKPD tersaji pada Gambar 6 .

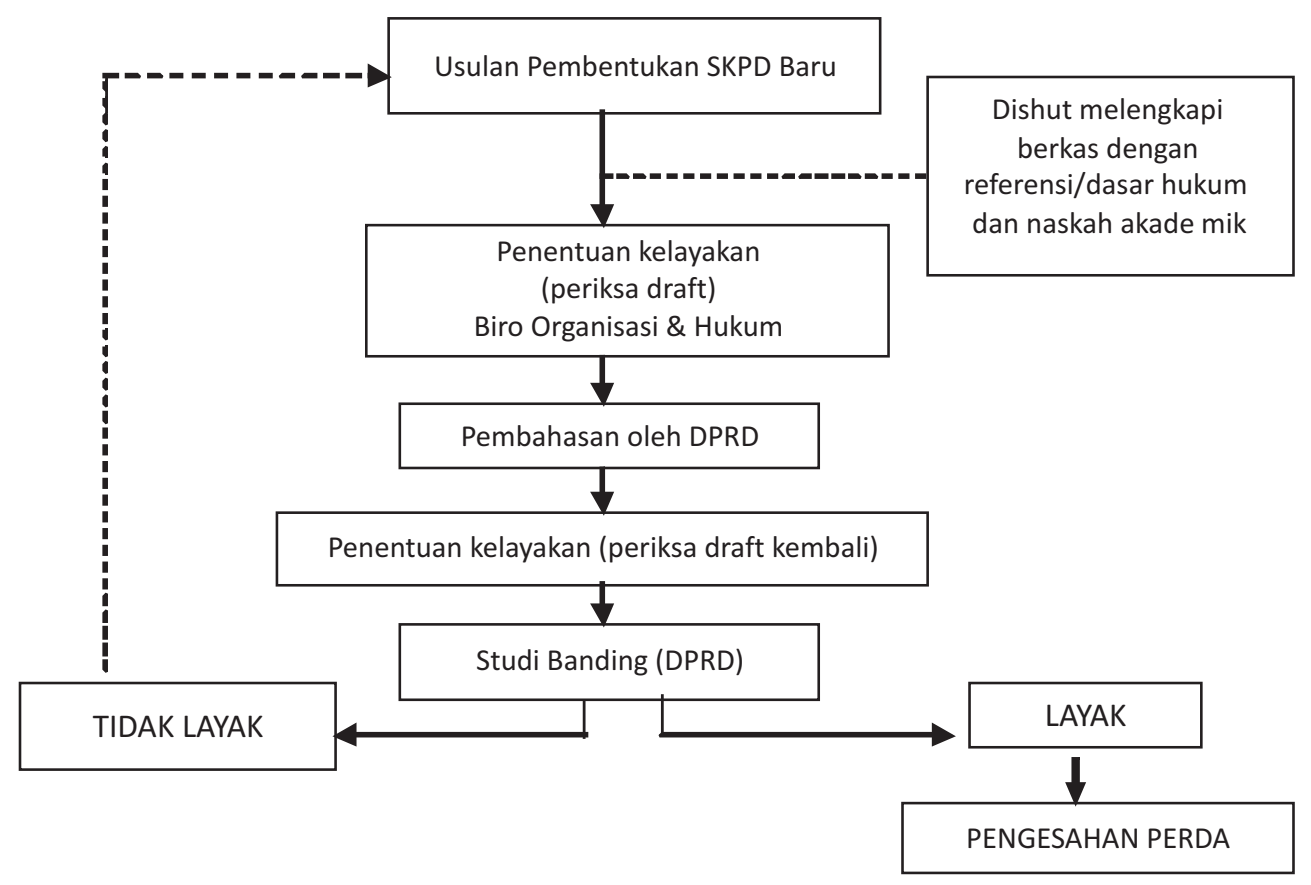

Gambar 6. Proses pembahasan Peraturan Daerah untuk membentuk SKPD baru Figure 6. Regulation making process for new $R W U$ formation 


\section{Sumberdaya Manusia, Sarana dan Prasarana Dalam Pembangunan KPH}

Suryono (2010) menjelaskan bahwa organisasi adalah suatu sistem yang terdiri dari pola aktivitas kerjasama yang dilakukan secara teratur dan berulang-ulang oleh sekelompok orang untuk mencapai suatu tujuan. Lebih lanjut, Suryono (2010) menjelaskan bahwa perilaku suatu organisasi dipengaruhi oleh 4 (empat) unsur antara lain struktur, orang atau SDM, teknologi dan lingkungan (kebijakan dan aturan). Dari pengertian di atas, apabila dikaitkan dengan pola pengelolaan $\mathrm{KPH}$ bahwa masih ada permasalahan dari aspek SDM dalam KPH.

\section{KPHP Banjar}

Ketersediaan SDM adalah salah satu syarat terbentuknya suatu organisasi, untuk KPH Banjar kondisi SDM dapat dilihat pada Tabel 5 berikut :

Tabel 5. Kondisi SDM di KPH Banjar

(Table 5. Human resources condition of Banjar FMU)

\begin{tabular}{clcccc}
\hline No & Jabatan (Position) & $\begin{array}{c}\text { Pendidikan } \\
\text { (Education) }\end{array}$ & $\begin{array}{c}\text { Pengalaman kerja } \\
\text { (Work experience) }\end{array}$ & $\begin{array}{c}\text { Gol. } \\
(\text { Rank) }\end{array}$ & $\begin{array}{c}\text { Kesesuaian } \\
\text { (Compatibility) }\end{array}$ \\
\hline 1 & Kepala unit UPTD KPH & S2 & Kehutanan & III/d & Sesuai \\
2 & Ka Tata Usaha & S2 & Kehutanan & III/c & Sesuai \\
3 & 2 Staf & S1 & Kehutanan & III/c & Sesuai \\
4 & 2 Staf & S1 & Kehutanan/Ekonomi & III/a & Sesuai \\
5 & 4 Polhut & D3 & Kehutanan & II/d & Sesuai \\
\hline
\end{tabular}

Sumber (Source) : Dinas Kehutanan Kabupaten Banjar (Banjar Forestry office) (2010)

Pengembangan Sumber Daya Manusia (SDM) harus selalu diupayakan secara terusmenerus untuk meningkatkan kinerja organisasi dan memelihara eksistensinya. Pengembangan SDM dalam hal ini adalah setiap usaha untuk memperbaiki pelaksanaan pekerjaan yang sekarang maupun yang akan datang, dengan memberikan informasi, mempengaruhi sikap atau menambah ketrampilan. SDM yang ada dalam KPH saat ini merupakan tenaga kerja dinas kehutanan yang dipekerjakan pada kantor KPH, dimana latar belakang semua tenaga kerja berpendidikan kehutanan dan sudah sesuai dengan bidang pekerjaannya. Jika KPH telah operasional secara penuh, maka para tenaga kerja tersebut akan dialihkan ke KPH dan merupakan tenaga kerja tetap. Apabila masih terdapat kekurangan SDM maka akan dilakukan recruitment SDM baru (fresh graduate) dengan latar belakang kehutanan dan bidang lain yang mendukung. Tenaga kerja ini bisa berasal dari SDM Pusat yang ada pada masing-masing UPT Kehutanan di daerah atau mutasi dari instansi lain. UPT pusat dalam hal ini BP2HP pada tahun 2010 memfasilitasi insentif untuk SDM yang ada di KPH Banjar sebanyak 7 (tujuh) orang (KKPH : Rp 1,5 juta/bulan, KTU : RP 1 juta/bulan dan 5 staff $@ \operatorname{Rp} 500.000 /$ bulan).

\section{KPHP Lalan Mangsang Mendis}

Jumlah SDM yang terdapat di KPH Lalan baru sejumlah 5 orang, sangat terbatas untuk pengelolaan kawasan hutan. Berdasarkan latar belakang pendidikannya SDM yang terdapat di KPH Lalan cenderung tidak sesuai atau tidak memiliki pendidikan formal kehutanan, walaupun memiliki pengalaman kerja di Dinas Kehutanan kabupaten Muba. Kondisi SDM KPH Lalan dapat dilihat pada Tabel 6 . 
Tabel 6. Kondisi SDM di KPH Lalan Mangsang Mendis

Table 6. Human resources condition in Lalan Mangsang Mendis FMU

\begin{tabular}{|c|c|c|c|c|c|c|}
\hline No & $\begin{array}{l}\text { Jabatan } \\
\text { (Position) }\end{array}$ & $\begin{array}{l}\text { Pendidikan } \\
\text { (Education) }\end{array}$ & $\begin{array}{c}\text { Pengalaman kerja / } \\
\text { Masa Kerja } \\
\text { (Work experience / } \\
\text { time) } \\
\end{array}$ & $\begin{array}{c}\text { Gol } \\
(\text { Rank })\end{array}$ & $\begin{array}{c}\text { Kesesuaian } \\
\text { (Compatibility) }\end{array}$ & $\begin{array}{l}\text { Keterangan } \\
\text { (Explanation) }\end{array}$ \\
\hline 1 & $\mathrm{KKPH}$ & $\begin{array}{l}\text { Sarjana } \\
\text { Pertanian }\end{array}$ & $\begin{array}{l}\text { Dishut } / 25 \text { tah un } \\
10 \text { bulan }\end{array}$ & $\begin{array}{c}\text { III c } \\
\text { Eselon IVa }\end{array}$ & Tidak sesuai & \\
\hline 2 & $\begin{array}{l}\text { Kepala Sub } \\
\text { Bagian Tata } \\
\text { Usaha }\end{array}$ & STM & $\begin{array}{l}\text { Dishut kab/ } 26 \\
\text { tahun } 6 \text { bulan }\end{array}$ & III c & Tidak sesuai & $\begin{array}{l}\text { Latar belakang } \\
\text { Polhut }\end{array}$ \\
\hline 3 & $\begin{array}{l}\text { Kaur } \\
\text { Perencanaan } \\
\text { dan Monev }\end{array}$ & $\begin{array}{l}\text { Sarjana } \\
\text { Hukum }\end{array}$ & $\begin{array}{l}\text { Dishut kab/ } 17 \\
\text { tahun } 3 \text { bulan }\end{array}$ & III b & Tidak sesuai & $\begin{array}{l}\text { Wasganis P3KB } \\
\text { (pengujian kayu } \\
\text { bulat) }\end{array}$ \\
\hline 4 & $\begin{array}{l}\text { Kaur Pem- } \\
\text { binaan dan } \\
\text { perlindungan } \\
\text { Hutan }\end{array}$ & SKMA & $\begin{array}{l}\text { Dishut kab/ } 22 \\
\text { tahun } 1 \text { bulan }\end{array}$ & III b & Sesuai & $\begin{array}{l}\text { Wasganis P3KB } \\
\text { (pengujian kayu } \\
\text { bulat) }\end{array}$ \\
\hline 5 & $\begin{array}{l}\text { Kaur Peman- } \\
\text { faatan \& } \\
\text { Penggunaan } \\
\text { Kaw. Hutan }\end{array}$ & $\begin{array}{l}\text { Sarjana } \\
\text { Ekonomi }\end{array}$ & $\begin{array}{l}\text { Dishut kab/ } 8 \\
\text { tahun } 5 \text { bulan }\end{array}$ & III c & Tidak sesuai & $\begin{array}{l}\text { Wasganis P3KB } \\
\text { (pengujian kayu } \\
\text { bulat) }\end{array}$ \\
\hline
\end{tabular}

Sumber (Source): Dishut Muba (2011)(Muba Forestry office (2011))

Dari Tabel 6 terlihat bahwa untuk jabatan KKPH, KTU dan dua kaur lainnya mempunyai latar belakang pendidikan yang tidak sesuai yaitu non kehutanan. Sementara itu golongan KKPH seharusnya sudah mencapai golongan minimal III d sebagaimana tertuang dalam Peraturan Menteri Kehutanan Republik Indonesia Nomor : P. 42/MenhutII/2011 tentang Standar Kompetensi Bidang Teknis Kehutanan pada KPHL dan KPHP.

$\mathrm{KPH}$ sebagai organisasi yang baru terbentuk tentunya memerlukan perencanaan SDM untuk menggerakkan roda organisasi. Langkah-langkah yang perlu dilakukan dalam perencanaan SDM antara lain pengumpulan data kegiatan yang dikembangkan organisasi, kebijakan strategis, kondisi dan pengembangan SDM, formasi jabatan dengan uraian kerja, analisis jabatan dan lain-lain (Sulistiyani dan Rosida, 2009). Dalam perencanaan SDM terdapat langkah-langkah pokok yaitu :

1. Perencanaan kebutuhan SDM.

2. Perencanaan untuk penerimaan tenaga baru dan seleksi sesuai kualifikasi yang diperlukan.

3. Perencanaan untuk pengembangan SDM yang telah ada.

Perencanaan kebutuhan SDM untuk $\mathrm{KPH}$ berdasarkan bentuk struktur organisasinya dan untuk tenaga teknis lapangan didasarkan atas luasan wilayah. Untuk tenaga teknis $\mathrm{KPH}$ disesuaikan dengan luasan $\mathrm{KPH}$ diluar kawasan IUPHHK, Hutan Desa, dan Hutan Tanaman Rakyat (HTR); serta kemampuan daerah untuk memenuhi SDM.

Rangkaian pelaksanaan perencanaan SDM juga terintegrasi dengan rencana suatu organisasi baik dalam jangka pendek maupun jangka panjang (Nawawi, 1997:144 dalam Sunarta, 2009). Selain memperhatikan struktur organisasi, perencanaan SDM yang akan datang terkait dengan perencanaan jangka panjang yang diuraikan dalam kegiatankegiatan yang digunakan sebagai masukan dari perencanaan operasional jangka menengah ke dalam tahap kegiatan perkiraan kebutuhan 
SDM dalam proses perencanaan SDM. Hasil perkiraan kebutuhan SDM tersebut dijadikan masukan secara integral dalam penyusunan anggaran tahunan ke dalam langkah perencanaan SDM.

Pengembangan SDM untuk KPHP diperlukan tenaga dengan keahlian yang sesuai dengan kompetensi Tenaga Tekhnis Pengelolaan Hutan Lestari (GANIS-PHL) dan Pengawas Tenaga Tekhnis Pengelolaan Hutan Lestari (WASGANIS-PHL) sebagaimana dalam P 58/Menhut-II/2008. WASGANISPHL adalah pegawai kehutanan yang memiliki kompetensi dibidang pengawasan dan pemeriksaan pengelolaan hutan produksi lestari sesuai dengan kualifikasinya yang diangkat dan diberhentikan oleh Kepala Balai atas nama Direktur Jenderal (Pasal 1 (16) P 58/2008). Oleh karena itu diperlukan koordinasi yang cukup baik antara KPH dengan UPT pusat sesuai kegiatan terkait.

Sumberdaya manusia dikatakan cukup dan memenuhi kualifikasi jika jumlah aparat pelaksana yang memenuhi persyaratan tertentu sesuai dengan aturan yang ditetapkan untuk melaksanakan kegiatan suatu organisasi (Akadira, 2010). Selain itu sumberdaya manusia harus memiliki pengetahuan dan keterampilan yang memadai dalam melaksanakan suatu kebijakan yang telah ditetapkan. Jumlah SDM yang banyak tidak selalu memiliki dampak yang positif bagi implementasi kebijakan, pelaksana kegiatan dalam hal ini staf dalam suatu organisasi harus memiliki keterampilan-keterampilan yang diperlukan dalam pelaksanaan kegiatan. Perencanaan untuk pengembangan yang sudah ada dilakukan dengan melalui pelatihanpelatihan teknis dan managemen administrasi untuk semua SDM yang ada di KPH. Selama ini hanya KKPH yang sudah mengikuti pelatihan teknis tentang perencanaan dan pengelolaan hutan.

\section{KESIMPULAN DAN REKOMENDASI}

\section{A. Kesimpulan}

1. Bentuk organisasi $\mathrm{KPH}$ saat ini adalah UPTD Dinas Kehutanan, yang mempunyai keterbatasan dalam anggaran, kewenangan pelaksanaan kegiatan, SDM baik kuantitas maupun kualitas dan ketidaksesuaian struktur organisasi dengan peraturan terkait.

2. KPH tidak dapat berbentuk Lembaga Teknis Daerah apabila skor besaran organisasi (PP41/2007) sudah menunjukkan nilai yang maksimal. Namun demikian $\mathrm{KPH}$ dapat berbentuk "Lembaga Lain" sesuai pasal 45 pada PP41/2007 melalui beberapa tahapan proses pembentukan SKPD baru di daerah.

3. Kebutuhan saat ini adalah bagaimana menguatkan kelembagaan $\mathrm{KPH}$ sebagai SKPD dengan perencanaan yang mengarah kepada bisnis sehingga kedepan dapat diarahkan untuk menjadi mandiri.

4. Pengembangan SDM pada kedua $\mathrm{KPH}$ sudah dilakukan melalui pelatihan dalam hal managemen administrasi dan teknis lapangan.

5. Perlu kebijakan yang lebih rinci mengenai bentuk SKPD KPH berdasarkan kategori $\mathrm{KPH}$ tipe A atau tipe B (Permendagri 61/ 2010), sehingga memudahkan implementasinya oleh daerah.

6. Kebijakan politis daerah dan urusan kehutanan sebagai pilihan merupakan tantangan bagi pemerintah daerah untuk mencapai transformasi kelembagaan $\mathrm{KPH}$ dari bentuk UPTD menjadi SKPD.

\section{B. Rekomendasi}

1. Persiapan untuk operasional KPH langkah awal yang perlu dilakukan adalah penentuan peran dan fungsi $\mathrm{KPH}$ secara 
jelas dan tata hubungan kerja dengan stakeholders terkait termasuk pemegang ijin yang dapat dituangkan melalui peraturan.

2. Perlu adanya komitmen daerah untuk mendukung pembentukan organisasi $\mathrm{KPH}$ dari UPTD menjadi SKPD sebagai evaluasi draft rancangan peraturan bersama antara Kemenhut dan Kemendagri.

3. Kelembagaan KPH yang berbentuk SKPD perlu adanya kebijakan yang mengatur sumber dana untuk satker (sumber perimbangan keuangan pusat dan daerah), sehingga dana yang ada dapat dikembalikan ke pengelolaan hutan secara lestari.

4. Dana pusat baik dekonsentrasi/DAK/ DIPA dan lainnya diarahkan untuk pembentukan SKPD dan operasional kegiatan KPH. Contoh : Sumber pendanaan bagi KPH dapat dilakukan bila dana dekonsentrasi dikurangi porsinya dan dialihkan ke fasilitasi $\mathrm{KPH}$

5. Perlu perencanaan SDM dengan langkahlangkah antara lain : Perencanaan kebutuhan SDM, penerimaan tenaga baru dan kualifikasi yang sesuai. Khusus untuk KPHP yang pada umumnya telah memiliki ijin, pengadaan SDM perlu disesuaikan kompetensinya dengan WASGANISPHL.

\section{DAFTAR PUSTAKA}

Akadira T. 2010. Faktor-faktor yang mempengaruhi Kinerja Organisasi. Tesis, tidak diterbitkan. FISIP, UI. Jakarta.

Azhar KA. 2008. Analisis Kinerja Keuangan Pemerintah Daerah Kabupaten Sebelum dan Sesudah Otonomi Daerah. Universitas Sumatera Utara. Medan.

Dinas Kehutanan Sumsel. 2009. Statistik Kehutanan Provinsi Sumatera Selatan. Palembang.
Dinas Kehutanan Muba. 2011. Data Kepegawaian Dinas kehutanan Kabupaten Musi Banyuasin. Sekayu.

Dinas Kehutanan Banjar. 2010. Statistik Kehutanan Kabupaten Banjar. Banjarbaru.

Ditjen Planologi. 2011. Perkembangan Penetapan Wilayah KPH sampai Agustus 2011. Jakarta.

Ditjen Planologi. 2010. Perkembangan Penetapan Wilayah KPH sampai April 2010. Jakarta.

Departemen Kehutanan. 2007. Pedoman Pembentukan Kelembagaan KPH. Ditjen Planologi, Dephut. Jakarta.

LAN. 2007. Modul Analisis dan Diagnostik Organisasi. Lembaga Administrasi Negara. Jakarta.

Nurrochmat,DR. 2010. Modul Pelatihan Analisis Kebijakan Kehutanan. Training for policy analysis and research report writing : Staretegies to produce a better policy brief. Puslitsosek, Badan Litbang Kementerian kehutanan. Bogor.

Kartodihardjo H. 2008. Presentasi Pembangunan KPH : Makalah Kerangka Hubungan Kerja Antar Lembaga Sebelum dan Setelah adanya KPH. Kerjasama dengan GTZ dan Dirjen Planologi, Kemenhut. Jakarta.

Parwiyanto H. 2009. Perilaku Organisasi : Perencanaan Sumberdaya Manusia. Universitas Sebelas Maret. Surakarta.

Sunarta. 2009. Perencanaan SDM : Kunci Keberhasilan Organisasi. FISE Universitas Negeri Yogyakarta.

Sulistiyani A dan Rosidah. 2009. Manajemen Sumberdaya Manusia : Konsep, Teori dan Pengembangan dalam Konteks 
Organisasi Publik. Graha Ilmu. Brawijaya. Universitas Brawijaya Yogyakarta. Malang.

Suryandari EY dan Sylviani. 2009. Rancangan Zainuddin, A. 2010. Manajemen Organisasi dan implementasi KPH. Laporan Hasil Penelitian. Puslitsosek, Kemenhut. Pemerintahan Daerah Membangun Kepemimpinan Modern Http:// Tidak diterbitkan.

Suryono A. 2010. Perilaku organisasi : Bahan Dc227.4shared.Com/Doc/E4dylakf/ Preview.Html.

Kuliah Kebijakan Publik Universitas 